\title{
PENGARUH PENDEKATAN PEMBELAJARAN STEM PROJECT-BASED LEARNING TERHADAP PEMAHAMAN KONSEP FISIKA SISWA
}

\author{
Petri Reni Sasmita ${ }^{1}$, Zainal Hartoyo ${ }^{2}$ \\ petrirenisasmita@gmail.com \\ ${ }^{1}$ Program Studi Pendidikan Fisika, Sekolah Tinggi Keguruan dan Ilmu Pendidikan Muhammadiyah Sungai Penuh, Kerinci \\ Jambi, Indonesia 37152 \\ ${ }^{2}$ Program Studi Tadris Fisika, Fakultas Tarbiyah dan Keguruan, Universitas Islam Negeri Sulthan Thaha Saifuddin Jambi, \\ Jambi, Indonesia 36361
}

Received: 2 Desember 2020

Revised: 3 Desember 2020

Accepted: 10 Desember 2020

\begin{abstract}
This study aims to determine the effect of the STEM Project-Based Learning approach on students' ability to understand physics concepts. The research method used was the pre-experimental research method with a one-group pretest-posttest design. The sampling technique used is cluster sampling method. Data collection used pretest and posttest to measure students' ability to understand physics concepts. The results of the effect size calculation show that the STEM Project-Based Learning approach has a major effect on students' ability to understand physics concepts. This study shows that the STEM Project-Based Learning approach has an influence on students' ability to understand physics concepts.

Abstrak: Penelitian ini bertujuan untuk mengetahui pengaruh pendekatan STEM Project-Based Learning terhadap kemampuan pemahaman konsep fisika siswa. Metode penelitian yang digunakan adalah metode penelitian eksperimen awal dengan desain one-group pretest-posttest design. Teknik pengambilan sampling menggunakan metode sampling kelompok (cluster sampling). Pengumpulan data menggunakan tes awal (pretest) dan tes akhir (posttest) untuk mengukur kemampuan pemahaman konsep fisika siswa. Hasil perhitungan effect size menunjukkan bahwa pendekatan STEM Project-Based Learning berpengaruh besar terhadap kemampuan pemahaman konsep fisika siswa. Penelitian ini menunjukkan bahwa pendekatan STEM Project-Based Learning memiliki pengaruh terhadap kemampuan pemahaman konsep fisika siswa.
\end{abstract}

Kata kunci: pemahaman konsep, pendekatan STEM Project-Based Learning, STEM, dan pembelajaran fisika.

\section{PENDAHULUAN}

Abad ke-21 menuntut setiap orang untuk menguasai ilmu pengetahuan dan teknologi (IPTEK). Pada abad ini, semua aktifitas kehidupan tidak terlepas dari teknologi. Untuk berkomunikasi dibutuhkan alat komunikasi yang merupakan produk teknologi komunikasi. Untuk melakukan perjalanan dibutuhkan alat transfortasi yang merupakan produk teknologi transfortasi. Untuk membangun tempat tinggal dibutuhkan alat konstruksi dan bahan bangunan yang merupakan produk teknologi konstruksi. Serta masih banyak lagi aktifitas kehidupan lainnya yang semuanya memanfaatkan teknologi. Teknologi tidak serta-merta muncul dengan sendirinya, teknologi membutuhkan ilmu pengetahuan sebagai dasarnya. 
Teknologi dan ilmu pengetahuan merupakan bagian dari kehidupan. Ilmu pengetahuan mempengaruhi teknologi, dan sebaliknya teknologi pun mempengaruhi ilmu pengetahuan. Begitu juga dengan kehidupan manusia sangat dipengaruhi oleh teknologi dan ilmu pengetahuan. Sehingga, teknologi dan ilmu pengetahuan tidak bisa dipisahkan dari kehidupan manusia.

Untuk menguasai IPTEK dibutuhkan sumberdaya manusia yang berkualitas yang dapat bertidak secara cepat, tepat, kreatif, dan inovatif. Oleh karena itu, pendidikan memiliki peranan penting untuk menciptakan sumber daya manusia yang berkualitas tersebut. Pendidikan merupakan pintu bagi umat manusia untuk menguasai ilmu pengetahuan dan teknologi. Tanpa pendidikan umat manusia akan buta, ibarat berjalan dimalam yang gelap tanpa cahaya yang menerangi. Seiring berkembangnya Ilmu Pengetahuan dan Teknologi (IPTEK) serta terjadinya perubahan dalam tatanan kehidupan bermasyarakat dan bernegara merupakan poin penting yang harus ditanggapi dan dipertimbangkan dalam pengembangan kurikulum pada setiap jenjang pendidikan. Pengembangan kurikulum merupakan sesuatu hal yang dapat terjadi kapan saja sesuai dengan kebutuhan. Perubahan kurikulum yang terakhir adalah Kurikulum 2013 (K13) yang diterapkan tepatnya pada bulan Juli 2013 (Karoror, I., Widyaningsih, S. W., Sebayang, S. R. B., \& Yusuf, I, 2020).

Sesuai dengan Undang-Undang Sistem pendidikan Nasional (Sisdiknas) Tahun 2003 pasal 3, fungsi pendidikan adalah mengembangkan kemampuan dan membentuk watak serta peradaban bangsa yang bermartabat dalam rangka mencerdaskan kehidupan bangsa. Hal ini, sejalan dengan tujuan kurikulum 2013 yaitu memperiapkan manusia Indonesia agar memiliki kemampuan hidup sebagai pribadi dan warga negara yang beriman, produktif, kreatif, inovatif, dan afektif serta mampu berkontribusi pada kehidupan masyarakat, berbangsa, bernegara, dan peradaban dunia. Maka, jelaslah bahwa untuk membangun peradaban bangsa dan bangsa yang bermartabat diperlukan pendidikan.

Pendidikan tidak akan pernah terlepas dari unsur-unsur pendidikan yang meliputi pendidik, peserta didik, dan sarana dan prasarana pendidikan. Semua unsur-unsur pendidikan tersebut harus memenuhi standar tertentu yang ditetapkan oleh Undang-undang. Sesuai dengan Undang-Undang Sisdiknas Tahun 2003 pasal 35 ayat 1, terdapat beberapa standar pendidikan, diantaranya yakitu: standar isi, standar proses, dan standar kompetensi lulusan.

Masing-masing standar pendidikan nasional tersebut saling berhubungan dan saling mempengaruhi. Sebagai tujuan pokok dari semua standar itu yaitu terciptanya lulusan yang memiliki kompetensi sesuai dengan standar kompetensi lulusan. Standar kompetensi lulusan 
pada jejang pendidikan menengah umum yaitu: (1) memiliki perilaku yang mencerminkan sikap orang beriman, berakhlak mulia, berilmu, percaya diri, dan bertanggung jawab dalam berinteraksi secara efektif dengan lingkungan sosial dan alam serta dalam menempatkan diri sebagai cerminan bangsa dalam pergaulan dunia; (2) memiliki pengetahuan faktual, konseptual, prosedural, dan metakognitif dalam ilmu pengetahuan, teknologi, seni, dan budaya dengan wawasan kemanusiaan, kebangsaan, kenegaraan, dan peradaban terkait penyebab serta dampak fenomena dan kejadian; (3) memiliki kemampuan pikir dan tindak yang efektif dan kreatif dalam ranah abstrak dan konkret sebagai pengembangan dari yang dipelajari di sekolah secara mandiri (Permendikbud No. 54, 2013). Untuk mewujudkan hal ini, tentunya diperlukan pencapaian standar isi pembelajaran dan standar proses pembelajaran terlebih dahulu.

Standar isi pembelajaran mencakup lingkup materi dan tingkat kompetensi untuk mencapai kompetensi lulusan (PP No. 19 pasal 25 ayat 1, 2005). Standar ini, berhubungan langsung dengan standar proses pembelajaran dan berdampak pada lulusan. Jika standar isi pembelajaran dan standar proses pembelajaran terpenuhi, maka diharapkan standar kompetensi lulusan juga tercapai. Standar isi pembelajaran dan standar proses pembelajaran ini dituangkan pada setiap mata pelajaran yang diajarkan di sekolah.

Sesuai dengan Kurikulum 2013 untuk jenjang Sekolah Menengah Atas (SMA), salah satu mata pelajaran yang wajib diajarkan kepada siswa adalah fisika (Permendikbud Nomor 69, 2013). Fisika merupakan produk dari metode ilmiah. Sehingga, proses pembelajaranya pun harus menggunkan metode ilmiah. Harapanya dengan menggunkan metode ilmiah proses pembelajaran akan menjadi menarik, memotivasi (Hartoyo, Rochman, \& Sasmita, 2018) dan menantang serta dapat menenamkan keterampilan ilmiah kepada siswa.

Pembelajaran sains pada kurikulum 2013 telah memberikan acuan dalam pemilihan model pembelajaran yang sesuai dengan pendekatan saintifik. Model pembelajaran yang dimaksud meliputi: Project Based Learning (PjBL), Problem Based Learning (PBL), atau Discovery Learning. Pemilihan model pembelajaran diserahkan kepada guru dengan menyesuaikan dengan karakteristik materi ajar. Pembelajaran saat ini perlu mengikuti perkembangan zaman di era globalisasi salah satunya dengan mengintegrasikan Science, Technology, Engineering, dan Mathematics (STEM). Keterkaitan antara sains dan teknologi maupun ilmu lain tidak dapat dipisahkan dalam pembelajaran sains. STEM merupakan displin ilmu yang berkaitan erat satu sama lain.Sains memerlukan matematika sebagai alat dalam mengolah data, sedangkan teknologi dan teknikmerupakan aplikasi dari sains. 
Pendekatan STEM dalam pembelajaran diharapkan dapat menghasilkan pembelajaran yang bermakna bagi siswa melalui integrasi pengetahuan, konsep, dan keterampilan secara sistematis. Beberapa manfaat dari pendekatan STEM membuat siswa mampu memecahkan masalah menjadi lebih baik, inovator, inventors, mandiri, pemikir logis, dan literasi teknologi (Afriana, J., Permanasari, A., \& Fitriani, A, 2016).

Proses pembelajaran fisika merupakan hal yang sangat penting dan berpengaruh terhadap keberhasilan pembelajaran. Oleh karena itu, diperlukan suatu standar mengenai proses pembelajaran fisika ini. Fisika merupakan ilmu yang mempelajari tentang fenomena gejala alam dan tak lepas dari penerapan kehidupan sehari-hari. Fisika juga merupakan ilmu universal yang mendasari perkembangan teknologi modern dan mempunyai peran penting dalam berbagai disiplin ilmu dan mengembangkan daya pikir manusia. Untuk menguasai dan meciptakan teknologi dimasa depan diperlukan penguasaan konsep-konsep Fisika sejak dini dan dilakukan suatu tindakan yang terencana. Oleh karena itu, Fisika berperan mempersiapkan siswa atau generasi penerus agar dapat menghadapi tantangan-tantangan di kehidupan yang semakin berkembang dan modern (Sasmita, P. R., Sakdiah, H., \& Hartoyo, Z, 2020). Standar tersebut tertuang dalam Peraturan Pemerintah (PP) Nomor 19 Tahun 2005 pasal 19 ayat 1 . Standar pembelajaran fisika ini menyebutkan bahwa proses pembelajaran fisika pada satuan pendidikan diselenggarakan secara interaktif, inspiratif, menyenangkan, menantang, memotivasi siswa untuk berpartisipasi aktif, serta memberikan ruang yang cukup bagi prakarsa, kreativitas, dan kemandirian sesuai dengan bakat, minat, dan perkembangan fisik serta psikologis siswa.

Di lain sisi, pembelajaran fisika yang dilaksanakan pada program peminatan IPA di salah satu sekolah di Kabupaten Kerinci belum menujukkan dukungan optimal terhadap standar proses pembelajaran fisika dan pencapaian kompetensi yang ditetapkan pada Kurikulum 2013. Hasil observasi terhadap pelaksanaan pembelajaran fisika pada salah satu SMA di Kabupaten Kerinci menunjukan beberapa kelemahan dalam pembelajaran fisika selama ini, yaitu: a) pembelajaran cenderung monoton dan tidak menantang, b) metode yang diguakan adalah metode yang bersifat informatif seperti ceramah dan tanya-jawab, c) media yang digunakan belum menunjang siswa untuk melakukan kegiatan praktikum, dan d) strategi yang digunkan belum memberdayakan kemampuan berpikir tingkat tinggi siswa. Lebih lanjut, hasil wawancara dengan siswa yang telah mengikuti pembelajaran fisika di sekolah mengungkap bahwa ketika mengikuti pembelajaran fisika mereka merasa bosan, mereka tidak terlibat aktif dalam proses pembelajaaran, dan meraka tidak diajak untuk melakukan 
praktikum dan membuat suatu proyek. Hal ini mengindikasikan bahwa siswa tidak terlatih dalam mengkonstruksi pengetahuannya melalui memahami konsep fisika. Fakta ini tidak sejalan dengan tuntutan Kurikulum 2013, kurikulum ini menghendaki pemahaman konsep fisika merupakan salah satu kemampuan yang harus dikuasai oleh siswa, demi terbentuknya kompetensi yang sesuai dengan standar kompetensi lulusan (Permendikbud No. 54, 2013).

Kemampuan memahami konsep fisika dapat dilatihkan melalui bermacam-macam model dan pendekatan pembelajaran yang sesuai dengan standar proses pembelajaran fisika seperti model pembelajaran Interactive Lecture Demonstrations (ILDs) (Sasmita, Sakdiah, \& Hartoyo, 2020). Walaupun demikian, pada tulisan ini, penulis menyatakan bahwa salah satu pendekatan pembelajaran yang sesuai dengan standar proses pembelajaran fisika dan dapat melatihkan pemahaman konsep fisika kepada siswa adalah pendekatan STEM Project-Based Learning (Capraro, Capraro, \& Morgan, 2013). Pendekatan pembelajaran ini mengharuskan siswa untuk terlibat aktif dalam seluruh rangkaian proses pembelajaran. Pendekatan pembelajaran ini juga menuntut siswa mengintegrasikan berbagai macam pengetahuan untuk mengkonstruksi pemahaman konsep fisika.

\section{LANDASAN TEORI}

\section{Pendekatan STEM Project-Based Learning}

STEM Project-Based Learning (Capraro et al., 2013) adalah:

an ill-defined task within a well-defined outcome situated with a contextually rich task requiring students to solve several problems which when considered in their entirety showcase student mastery of several concepts of various STEM subjects.

Hasil yang didefinisikan dengan baik (well-defined outcome) merujuk pada tujuan pembelajaran yang disesuaikan dengan standar nasional, harapan dan kendala dalam menyelesaikan tugas (Capraro et al., 2013). Sedangkan, tugas tidak jelas (ill-defined task) memungkinkan siswa untuk bebas menafsirkan masalah, kendala, dan kreteria berdasarkan pengetahuan mereka mengenai materi pelajaran untuk merumuskan solusi yang beragam demi mencapai hasil yang telah didefinisikan dengan baik (Capraro et al., 2013).

Pendekatan STEM Project-Based Learning berhubungan erat dengan teknik (engineering). Teknik merupakan jantung dari pendekatan STEM Project-Based Learning. Teknik merupakan aplikasi konsep dari matematika, sains, dan teknologi yang bertujuan untuk memecahkan permasalahan yang komplek dalam cara yang sistematis (Morgan, et al, 2013). Untuk memecahkan masalah secara sistematis, diperlukan krativitas dalam 
menerapkan prinsip-prinsip ilmiah. Teknik berhubungan langsung dengan masalah dunianyata (real-world problems), hal ini memberikan konteks yang baik untuk mengilustrasikan konsep-konsep lain yang mungkin sulit bagi siswa untuk memvisualisasikannya.

Teknik dibangun menggunakan desain teknik (engineering disign process). Desain proses teknik terdiri atas tujuh langkah proses (Morgan, Moon, \& Barroso, 2013), yaitu (1) mengidentifikasi masalah dan kendala (Identify Problem and Constraints),(2) penelitian (Research), (3) membangun ide (Ideate), (4) menganalisis ide (analyze ideas), (5) membuat (build), (6) pengujian dan perbaikan (Test and Refine), dan (7) mengkomunikasikan dan merefleksikan (Communicate and Reflect).

Desain proses teknik yang merupakan bagian integaral dari STEM Project-Based Learning jika diterapkan dalam proses pembelajaran tidak bisa berdiri sendiri, sehingga membutuhkan model pembelajaran tertentu untuk menerapkannya. Oleh karena itu, penerapan STEM Project-Based Learning dalam proses pembelajaran dalam penelitian ini menggunkan model 5E. Model pembelajaran yang cocok dengan desain proses teknik adalah model 5E (Bybee et al., 2006), hal ini dikarenakan model ini menyediakan struktur langkahlangkah pembelajaran. Penggabungan langkah-langkah model 5E dengan desain proses teknik (Morgan et al., 2013) secara lengkap ditunjukkan pada Tabel 1.

Tabel 1. Penggabungan model 5E dengan desain proses teknik

\begin{tabular}{ll}
\hline Langkah-langkah model 5E & Langkah desain proses \\
\hline Engagement & Identify problem and constraints \\
Exploration & Research; Ideate; Analyze ideas \\
Explanation & Research; Ideate; Analyze ideas \\
Extension & Build; Communicate \\
Evaluation & Test and refine; Reflect \\
\hline
\end{tabular}

\section{Kemampuan Pemahaman Konsep Fisika}

Kemampuan pemahaman konsep fisika adalah kemampuan siswa dalam memaknai konsep atau arti fisis dari konsep (Engelhardt \& Beichner, 2004). Proses kognitif yang menyangkut kemampuan pemahaman konsep berdasarkan taxonomi Bloom yang direvisi (Anderson et al., 2001) adalah: (1) menafsirkan (interpreting), (2) mencontohkan (exemplifying), (3) mengklasifikasikan (classifying), (4) meringkas (summarizing), (5) menarik inferensi (inferring), (6) membandingkan (comparing), dan (7) menjelaskan (explaining). 
1. Menafsirkan (interpreting)

Menafsirkan terjadi ketika siswa mampu mengubah suatu informasi dari satu bentuk informasi ke bentuk informasi yang lainnya. Kemampuan ini meliputi kemampuan mengubah kata-kata ke grafik atau gambar atau sebaliknya, dari kata-kata ke angka atau sebaliknya, maupun dari kata-kata ke kata-kata lain (Anderson et al., 2001). Kemampuankemampuan dalam proses menafsirkan yakni: (1) menerjemahkan suatu abstraksi menjadi abstraksi dalam bahasa yang lain, (2) menerjemahkan suatu bentuk simbolik ke bentuk simbolik yang lain atau sebaliknya.

2. Mencontohkan (exemplifying)

Peoses kognitif mencontohkan terjadi manakala siswa mampu memberikan contoh khusus dari suatu konsep atau prinsip yang bersifat umum (Anderson et al., 2001). Memberikan contoh menuntut kemampuan mengidentifikasi ciri-ciri pokok suatu konsep atau prinsip umum dan selanjutnya menggunakan ciri-ciri tersebut untuk memilih atau membuat contoh.

\section{Mengklasifikasikan (classifying)}

Proses kognitif mengklasifikasikan terjadi ketika siswa mengetahui bahwa sesuatu (benda atau fenomena) masuk dalam kategori konsep atau prinsip tertentu (Anderson et al., 2001). Mengklasifikasikan melibatkan proses mendeteksi cici-ciri atau pola-pola yang sesuai dengan contoh tertentu dan konsep atau prinsip tersebut. Termasuk dalam kemampuan mengklasifikasikan adalah mengenali ciri-ciri yang dimiliki suatu benda atau fenomena. Istilah lain untuk mengkalsifikasikan adalah mengkategorisasikan (categorising).

\section{Merangkum (summarizing)}

Proses kognitif merangkum terjadi ketika siswa mengemukahkan suatu kalimat yang merepresentasikan informasi yang diterima atau mengabstraksi sebuah tema (Anderson et al., 2001). Kemampuan meringkas terbentuk dalam diri siswa ketika siswa mampu membuat suatu pernyataan yang mewakili seluruh informasi. Meringkas menuntut siswa untuk memilih inti dari suatu informasi dan meringkasnya. Istilah lain untuk meringkas adalah menggeneralisasi (generalising) dan mengabstraksi (abstracting).

\section{Menyimpulkan (inferring)}

Proses kognitif menyimpulkan menyertakan proses menemukan pola dalam sejumlah contoh. Menyimpulkan terjadi ketika siswa dapat mengabstraksi sebuah konsep atau prinsip yang menerangkan contoh-contoh tersebut dengan mencermati ciri-ciri setiap contohnya dan yang terpenting dengan menarik hubungan diantara ciri-ciri tersebut 
(Anderson et al., 2001). Untuk dapat melakukan penyimpulan siswa harus terlebih dahulu dapat menarik abstraksi suatu konsep/prinsip berdasarkan sejumlah contoh yang ada. Istilah lain untuk menyimpulkan adalah mengekstrapolasi (extrapolating), menginterpolasi (interpolating), memprediksi (predicting), dan menarik kesimpulan (concluding).

6. Membandingkan (comparing)

Proses kognitif membandingkan melibatkan proses mendeteksi persamaan dan perbedaan antara dua atau lebih objek, peristiwa, ide, masalah, atau situasi (Anderson et al., 2001). Membandingkan mencakup juga menemukan kaitan antara unsur-unsur satu objek atau keadaan dengan unsur yang dimiliki objek atau keadaan lain. Istilah lain untuk membandingkan adalah mengkontraskan (contasting), mencocokkan (matching), dan memetakan (mapping).

7. Menjelaskan (explaining)

Proses kognitif menjelaskan berlangsung ketika siswa dapat membuat dan menggunakan model sebab-akibat dalam sebuah sistem (Anderson et al., 2001). Model ini dapat diturunkan dari teori atau didasarkan pada hasil penelitian atau pengalaman. Termasuk dalam "menjelaskan" adalah menggunakan model tersebut untuk mengetahui apa yang terjadi apabila salah satu bagian sistem tersebut diubah.

Proses kognitif pemahaman konsep tersebut memiliki tujuh indikator proses kognitif. Namun, dalam penelitian ini indikator tersebut tidak semuanya diukur. Adapun indikator proses kognitif kemampuan pemahaman konsep yang diukur dalam penelitian ini adalah : menafsirkan, mencontohkan, menginferensi, membandingkan, dan menjelaskan.

\section{METODE PENELITIAN}

Metode penelitian yang digunakan dalam penelitian ini adalah metode eksperimen awal dengan desain one-group pretest-posttest design (Fraenkel, J. R., Wallen, N. E., \& Hyun, 2012). Penelitian dilaksanakan di salah satu sekolah menengah atas (SMA) di Kabupaten Kerinci pada siswa kelas XI. Teknik pengambilan sampling menggunakan metode sampling kelompok (cluster sampling). Pengambilan data dilakukan dengan cara memberikan tes awal (pretest) kepada siswa sebelum pembelajaran dengan pendekatan STEM Project-Based Learning dilaksanaan dan setelah pembelajaran dengan pendekatan STEM Project-Based Learning dilaksanakan siswa diberikan tes akhir (posttest). Data yang diperoleh kemudian diolah menggunakan perhitungan N-gain (Hake, 2012) dan effect size (Dunst, Hamby, \& Trivette, 2004). N-Gain digunakan untuk mengetahui peningkatan kemampuan pemahaman 
konsep fisika siswa, sedangkan effect size digunakan untuk menentukan pengaruh pendekatan STEM Project-Based Learning terhadap kemampuan pemahaman konsep fisika siswa.

$\mathrm{N}$-Gain dihitung dengan menggunakan persamaan sebagai berikut :

$$
<g>=\frac{\left(\%<S_{f}>-\%<S_{i}>\right)}{\left(100-\%<S_{i}>\right)}
$$

Keterangan:

$\langle g\rangle \quad=$ rerata skor gain yang dinormalisasi

$S_{f} \quad=$ skor tes akhir

$S_{i} \quad=$ skor tes awal

Skor rerata gain yang dinormalisasi $(<\mathrm{g}\rangle)$ diinterpretasikan kedalam kriteria tertentu yang meliputi tinggi, sedang, dan rendah. Kriteria skor rerata gain yang dinormalisasi $(<\mathrm{g}\rangle)$ secara lengkap ditunjukkan pada Tabel 2.

Tabel 2. Kriteria skor rerata gain yang dinormalisasi $(\langle\mathrm{g}\rangle)$

\begin{tabular}{cc}
\hline Kategori Persentase rerata N-gain & Kriteria \\
\hline $0,70>(<\mathrm{g}>)$ & Tinggi \\
$0,30 \leq(<\mathrm{g}>) \leq 0,70$ & Sedang \\
$(<\mathrm{g}>)<0,30$ & Rendah
\end{tabular}

Sumber: Hake, (2012)

Persamaan effect size yang digunakan dalam penelitian ini adalah sebagai berikut:

$$
d=\frac{M_{\text {posttest }}-M_{\text {pretest }}}{\sqrt{\frac{S D_{\text {posttest }}^{\mathrm{g}}+S D_{\text {pretest }}^{\mathrm{g}}}{2}}}
$$

Keterangan:

$M=$ Rata-rata skor tes

$S D=$ Standar deviasi skor tes

Skor effect size $(d)$ yang diperoleh dari persamaan tersebut kemudian diintepretasikan dengan menggunakan kriteria di bawah ini:

Tabel 3. Interpretasi effect size

\begin{tabular}{cc}
\hline Skor Effect size $(d)$ & Interpretasi \\
\hline$d<0,2$ & Sangat Kecil \\
$0,2 \leq d<0,5$ & Kecil \\
$0,5 \leq d<0,8$ & Sedang \\
$0,8 \leq d<1,0$ & Besar \\
$d \geq 1,0$ & Sangat Besar \\
\hline
\end{tabular}

Puplished at https://ojs.stkippgri-lubuklinggau.ac.id/index.php/SJPIF 
Sumber: Dunst, Hamby, \& Trivette, (2004)

\section{HASIL DAN PEMBAHASAN}

Hasil rekapitulasi perolehan rerata skor tes awal (pretest) dan tes akhir (posttest) kemampuan pemahaman konsep fisika siswa menunjukkan bahwa peningkatan kemampuan pemahaman konsep siswa cukup tinggi. Rata-rata skor N-Gain kemampuan pemahaman konsep fisika siswa adalah sebesar 0,52 seperti terterah pada Tabel 2. Rata-rata skor N-Gain ini jika dicocokkan dengan katagori skor N-Gain pada Tabel 2 berada pada kategori sedang.

Tabel 4. Rekapitulasi tes awal (pretest), dan tes akhir (posttest), dan N-Gain kemampuan pemahaman konsep fisika siswa

\begin{tabular}{lcc}
\hline Deskripsi & \multicolumn{2}{c}{ Tes } \\
\cline { 2 - 3 } Skor Maksimum & Pretest & Posttest \\
Skor Minimum & 16,50 & 95,00 \\
Skor Rata-rata & 42,75 & 62,50 \\
$N$-gain & \multicolumn{2}{c}{0,52} \\
\hline
\end{tabular}

Berdasarkan Tabel 4, dapat diketahui bahwa skor maksimum dan minimum tes akhir (posttest) lebih tinggi dari skor maksimum dan minimum tes awal (pretest). Hal ini mengindikasikan bahwa adanya pengaruh pendekatan STEM Project-Based Learning terhadap pemahaman konsep fisika siswa. Selain itu juga, dari data N-Gain dapat diketahui bahwa kemampuan pemahaman konsep fisika siswa mengalami peningkatan yang cukup tinggi, dengan skor N-gain sebesar 0,52 yang berada pada kategori sedang. Skor N-gain yang berada pada kategori sedang ini menunjukkan bahwa adanya pengaruh pendekatan STEM Project-Based Learning terhadap pemahaman konsep fisika siswa.

Hasil rekapitulasi N-Gain berdasarkan indikator kemampuan pemahaman konsep fisika siswa menunjukkan adanya peningkatan pemahaman konsep fisika pada setiap indikator pemahaman konsep fisika siswa. Peningkatan tertinggi terjadi pada indikator mencontohkan dengan skor $\mathrm{N}$-Gain sebesar 0,71 dan peningkatan terendah terjadi pada indikator menafsirkan, seperti ditunjukkan pada Gambar 1. 


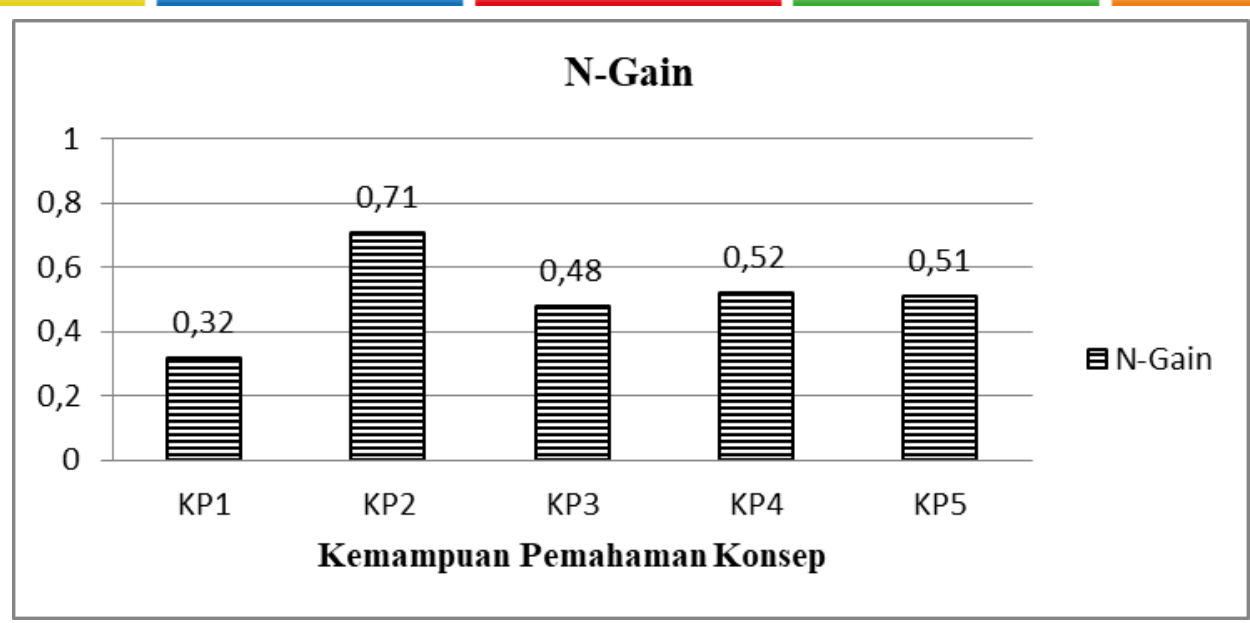

Keterangan: KP1 = Menafsirkan, KP2 = Mencontohkan, KP3 = Menginferensi, KP4 = Membandingkan, KP5 = Menjelaskan

Gambar 1. Hasil perhitungan N-Gain kemampuan pemahaman konsep siswa berdasarkan setiap indikatornya

Melalui Gambar 1 dapat diketahui bahwa N-Gain indikator menafsirkan, menginferensi, membandingkan dan menjelaskan berada pada kategori sedang, sedangkan N-Gain indikator mencontohkan berada pada kategori tinggi. Lebih lanjut, dapat diketahui juga bahwa setiap indikator menunjukan adanya pengingkatan kemampuan pemahaman konsep fisika siswa.

Hasil perhitungan effect size dengan menggunakan rumus Cohen terhadap tes awal dan tes akhir diperoleh skor $d$ sebesar 0,83. Jika, skor $d$ ini dicocokan dengan kategori effect size pada Tabel 3, maka akan diketahui bahwa skor $d$ berada pada kategori besar. Hal ini mengindikasikan bahwa pendekatan STEM Project-Based Learning memiliki pengaruh terhadap kemampuan pemahaman konsep fisika siswa.

Sesuai dengan hasil perhitungan skor rata-rata N-gain di atas dapat diketahui bahwa skor rata-rata $\mathrm{N}$-gain adalah 0,52 yang berada pada kategori sedang. Hal ini menunjukkan bahwa pendekatan STEM Project-Based Learning dapat meningkatkan kemampuan pemahaman konsep fisika siswa. Jika ditinjau dari masing-masing indikator kemampuan pemahaman konsep, pendekatan STEM Project-Based Learning juga dapat meningkatkan kemampuan pemahaman konsep fisika siswa. Hal ini dibuktikan dengan skor N-gain pada setiap indikator kemampuan pemahaman konsep yakni skor $\mathrm{N}$-gain menafsirkan sebesar 0,31 , mencontohkan sebesar 0,71, menginferensi sebesar 0,48, membandingkan sebesar 0,52 dan menjelaskan sebesar 0,51 .

Sesuai dengan hasil perhitungan skor effect size di atas, diperoleh sekor $d=0,83$ yang berada pada kategori besar. Dari hasil ini dapat kita katakan bahwa pendekatan STEM 
Project-Based Learning memiliki pengaruh terhadap peningkatan kemampuan pemahaman konsep fisika siswa. Oleh karena itu, dapat disimpulkan bahwa pengimplementasian pendekatan STEM Project-Based Learning dalam pembelajaran fisika memiliki pengaruh yang besar terhadap peningkatan kemampuan pemahaman konsep fisika siswa.

\section{KESIMPULAN DAN SARAN}

\section{SIMPULAN}

Pedekatan STEM Project-Based Learning dapat meningkatkan kemampuan pemahaman konsep fisika siswa, dengan rata-rata N-Gain adalah 0,52 yang berada pada kategori sedang. Selanjutnya, Pedekatan STEM Project-Based Learning ini juga berpengaruh terhadap kemampuan pemahaman konsep fisika siswa, dengan skor effect size adalah 0,83 yang berada pada kategori besar.

\section{SARAN}

Guna mengetahui lebih jauh mengenai perbandingan pendekatan STEM Project-Based Learning dengan pendekatan pembelajaran lain dalam meningkatkan pemahaman konsep fisika siswa, diperlukan kajian yang melibatkan lebih banya kelas pembelajaran fisika.

\section{DAFTAR PUSTAKA}

Afriana, J., Permanasari, A., \& Fitriani, A. (2016). Penerapan project based learning terintegrasi STEM untuk meningkatkan literasi sains siswa ditinjau dari gender. Jurnal Inovasi Pendidikan IPA, 2(2), 202-212.

Anderson, L. W., Krathwohl Peter W Airasian, D. R., Cruikshank, K. A., Mayer, R. E., Pintrich, P. R., Raths, J., \& Wittrock, M. C. (2001). Taxonomy for_Assessing a Revision OF BlOOM'S TaxONOMy OF EducatiONal Objectives. Retrieved from https://www.uky.edu/ rsand1/china2018/texts/Anderson-Krathwohl - A taxonomy for learning teaching and assessing.pdf

Bybee, R. W., Taylor, J. a, Gardner, A., Van, P., Powell, J. C., Westbrook, A., ... Knapp, N. (2006). The BSCS 5E Instructional Model: Origins and Effectiveness. A Report prepared for the Office of Science Education and National Institutes of Health. Science, (June).

Capraro, R. M., Capraro, M. M., \& Morgan, J. R. (2013). STEM Project-Based Learning. Boston: Sense Publishers.

Dunst, C. J., Hamby, D. W., \& Trivette, C. M. (2004). Guidelines for Calculating Effect Sizes 
for Practice-Based Research Syntheses. 3(1).

Engelhardt, P. V., \& Beichner, R. J. (2004). Students' understanding of direct current resistive electrical circuits. American Journal of Physics, 72(1), 98-115. https://doi.org/10.1119/1.1614813

Fraenkel, J. R., Wallen, N. E., \& Hyun, H. H. (2012). How to Design and Evaluate Research in Education (8th, ed.). New York: McGraw-Hill.

Hake, R. R. (2012). Interactive-engagement versus traditional methods: A six-thousandstudent survey of mechanics test data for introductory physics courses Interactiveengagement versus traditional methods: A six-thousand-student survey of mechanics test data for introduc. 64(1998). https://doi.org/10.1119/1.18809

Hartoyo, Z., Rochman, S., \& Sasmita, P. R. (2018). Analisis motivasi mahasiswa dalam belajar fisika. Science and Physics Education Journal (SPEJ), 1(2).

Karoror, I., Widyaningsih, S. W., Sebayang, S. R. B., \& Yusuf, I. (2020). Upaya Meningkatkan Hasil Belajar Peserta Didik melalui Penerapan Model Kooperatif Tipe The Power Of Two Berbasis Alat Peraga di Kelas VII SMP Yapis Manokwari. Silampari Jurnal Pendidikan Ilmu Fisika, 2(1), 66-76.

Morgan, J. R., Moon, A. M., \& Barroso, L. R. (2013). Steps of Design Process (Sense Publ). Boston.

Sasmita, P. R., Sakdiah, H., \& Hartoyo, Z. (2020). Pengaruh Penerapan Model Pembelajaran Interactive Lecture Demonstrations (ILDs) Terhadap Kemampuan Pemahaman Konsep Fisika Siswa. Silampari Jurnal Pendidikan Ilmu Fisika, 2.

Sasmita, P. R., Sakdiah, H., \& Hartoyo, Z. (2020). Pengaruh Penerapan Model Pembelajaran Interactive Lecture Demonstrations (ILDs) Terhadap Kemampuan Pemahaman Konsep Fisika Siswa. Silampari Jurnal Pendidikan Ilmu Fisika, 2(1), 55-65. 